\title{
Case Report \\ Renal Cell Carcinoma of the Kidney with Synchronous Ipsilateral Transitional Cell Carcinoma of the Renal Pelvis
}

\author{
Dogan Atilgan, Nihat Uluocak, and Bekir Suha Parlaktas \\ Gaziosmanpasa University Faculty of Medicine Department of Urology, 60100 Tokat, Turkey
}

Correspondence should be addressed to Dogan Atilgan; datilgan@msn.com

Received 30 April 2013; Accepted 6 June 2013

Academic Editors: J. P. Gearhart, C. Liao, and G. Lombardi

Copyright (C) 2013 Dogan Atilgan et al. This is an open access article distributed under the Creative Commons Attribution License, which permits unrestricted use, distribution, and reproduction in any medium, provided the original work is properly cited.

\begin{abstract}
A 73-year-old man was admitted to our clinic with flank pain and gross macroscopic hematuria. Radiologic examination revealed a solid mass in the left kidney and additionally another mass in the ureteropelvic junction of the same kidney with severe hydronephrosis. Left nephroureterectomy with bladder cuff removel was performed, and histopathological evolution showed a Fuhrman grade 3 clear cell type RCC with low-grade TCC of the pelvis.
\end{abstract}

\section{Introduction}

Simultaneous occurrence of renal cell carcinoma (RCC) and transitional cell carcinoma (TCC) in the ipsilateral kidney is a rare entity. There are only about 50 cases reported in the literature to date [1-3].

Herein, we reported a 73-year-old man who admitted to our clinic with simultaneous RCC and TCC of the left kidney.

\section{Case Presentation}

A 73-year-old man who he had suffered from with left flank pain and hematuria was admitted to our clinic. Physical examination and laboratory findings were normal. Patient has a history of ischemic heart disease and 1 pack of cigarette smoking for 40 years. The USG showed grade 4 hydronephrosis and a solid mass with $5 \mathrm{~cm}$ diameter in the left kidney. Computed tomography revealed several hydronephrosis and a solid mass with $52 \times 41 \mathrm{~mm}$ diameters in the middle part of the left kidney. Additionally, a $50 \times$ $45 \times 38 \mathrm{~mm}$ solid mass was detected at the ureteropelvic junction (UPJ) of the same kidney with normal contralateral kidney (Figures 1 and 2). There was no evidence of metastasis. Cystoscopy revealed no pathological findings, and subsequently left nephroureterectomy with lymphadenectomy was performed. Macroscopic evaluation of the specimen showed severe hydronephrotic left kidney with thin parenchyma and a solid mass with $70 \times 70 \times 5.5 \mathrm{~mm}$ diameters located in the middle part of the kidney without capsular penetration. In addition, a $60 \times 50 \times 40 \mathrm{~mm}$ diameters solid mass with papillomatous components was detected at the ureteropelvic junction (Figure 3). Microscopically, parenchymal mass was detected as a Fuhrman 3 clear cell type RCC, and papillosolid mass at the UPJ was detected as a noninvasive low-grade papillary urothelial carcinoma (Figures 4 and 5). Surgical margins were negative for both tumors. Postoperative 5th day patient was discharged without any complication, and no problems occurred during follow-up period.

\section{Discussion}

RCC is the commonest solid lesion of the kidney and accounts for approximately $90 \%$ of all kidney malignancies [4]. Conversely, primary transitional cell carcinoma (TCC) of the renal pelvis or ureter is a relatively rare disease, and it accounts for less than $1 \%$ of genitourinary neoplasms and 5$7 \%$ of all urinary tract tumours [5]. Synchronous ipsilateral TCC of the renal pelvis and RCC rarely have been reported in the literature.

Several possible aetiological factors have been implicated for primary renal pelvic neoplasms. Although the etiology of coexistence of different type renal neoplasms is still unclear, 


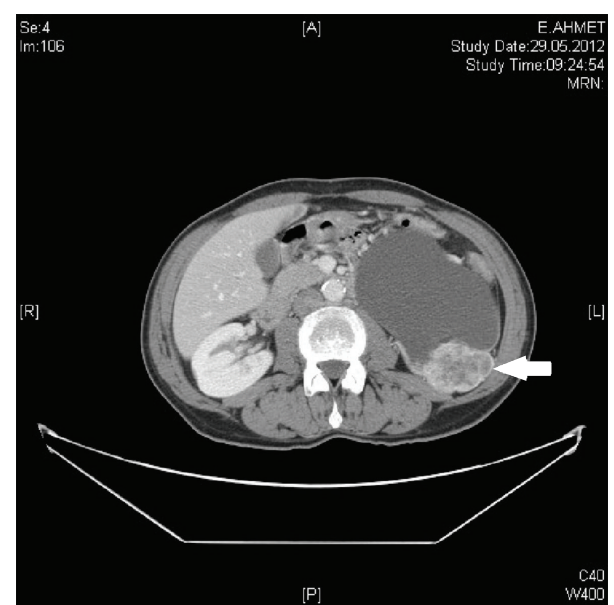

Figure 1: CT image of the solid renal parenchymal mass in the left kidney.

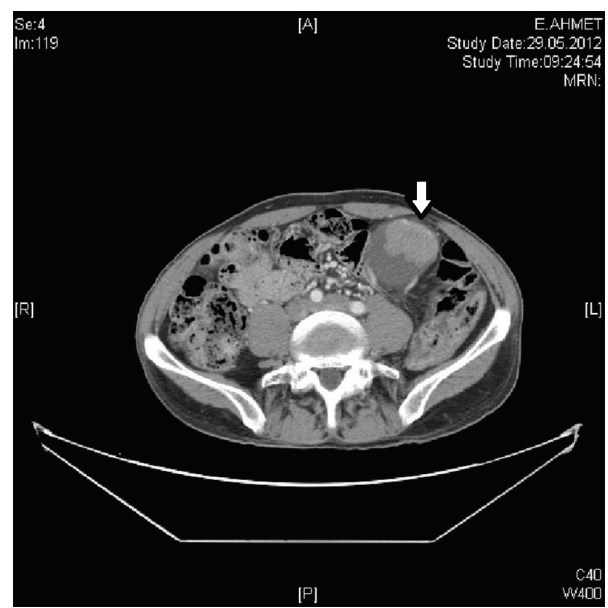

FIGURE 2: CT image of the solid mass in the left ureteropelvic junction with severe hydronephrosis.

chronic irritation, hydronephrosis, and urinary calculi have been the most commonly discussed etiologic factors [6].

The symptoms of the synchronous RCC and TCC are similar to the solitary RCC or TCC of the kidney. The most common symptom at presentation was haematuria which was seen in $90 \%$ of the cases $[7,8]$. The mean age at presentation was 65 , and male/female ratio was $2 / 1$. The tumors were commonly located on the left kidney $[9,10]$. The standard treatment of RCC is the radical nephrectomy or partial nephrectomy for thus small renal carcinomas. However, recurrence rate in the ipsilateral ureteral stump is stated as $30-7 \%$ for TCC of the kidney, and high grade recurrences in ureteral stump are associated with poor prognosis [11]. Because of that, in such cases with synchronous TCC and RCC of the same kidney, ureterectomy with partial cystectomy should be added to the treatment. Furthermore, synchronous or metachronous bladder TCC due to seeding of the tumor cells may occur approximately in $45 \%$ of upper

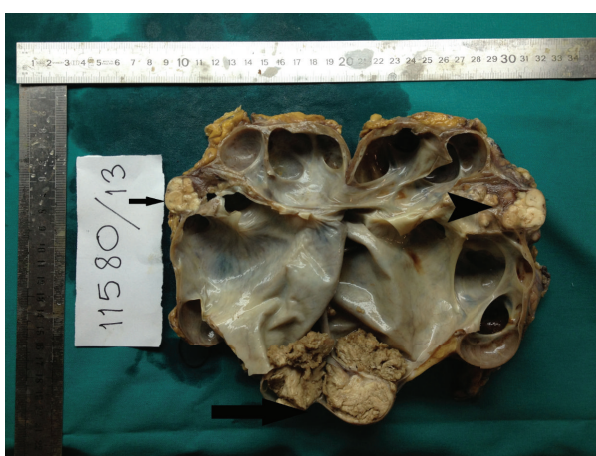

FIgURE 3: Macroscopic view of RCC (small arrow) and TCC (large arrow) with severe hydronephrosis.

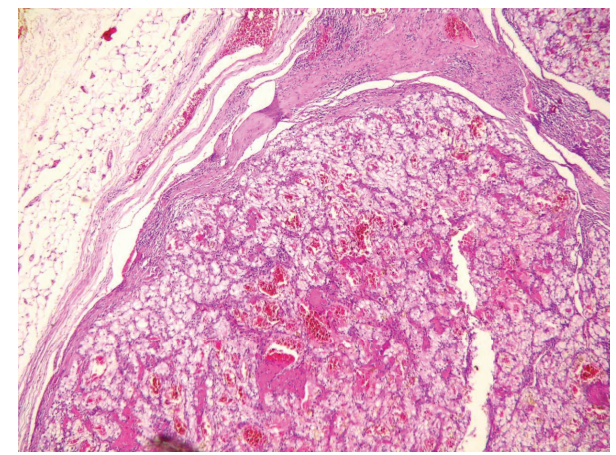

FIgURE 4: Microscopic overview of the RCC $(\mathrm{H}-\mathrm{E}, \times 30)$.

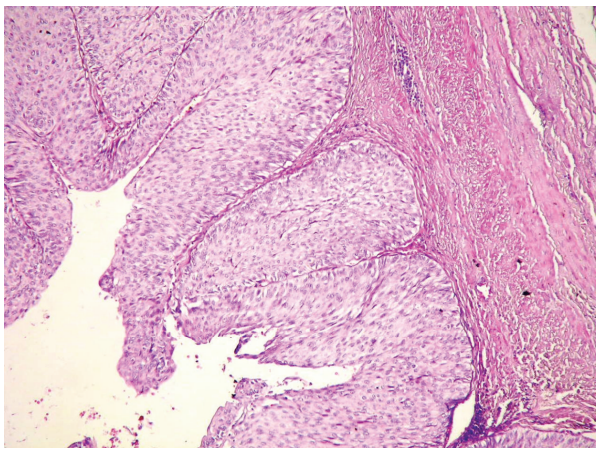

Figure 5: Papillary urothelial carcinoma (H-E, $\times 30)$.

urinary tract TCCs [12]. Therefore, cystoscopic evaluation of the bladder should be performed preoperatively.

Although synchronous RCC and TCC of the same kidney are a rare condition and there is no certain opinion about the treatment, radical nephroureterectomy with bladder cuff removal may be curative, especially in low-grade tumors.

\section{References}

[1] M. Fernández Arjona, D. Santos Arrontes, F. De Castro Barbosa, F. Begara Morillas, I. Cortes Aranguez, and L. Gonzalez, "Clear cell renal carcinoma and synchronous ipsilateral urothelial carcinoma: contribution of a new case and literature review," Archivos Espanoles de Urologia, vol. 58, no. 5, pp. 460-463, 2005. 
[2] A. Demir, F. F. Önol, S. Bozkurt, and L. Türkeri, "Synchronous ipsilateral conventional renal cell and transitional cell carcinoma," International Urology and Nephrology, vol. 36, no. 4, pp. 499-502, 2004.

[3] H. E. H. Wegner, G. Bornhoft, and K.-P. Dieckmann, "Renal cell cancer and concomitant transitional cell cancer of the renal pelvis and ureter in the same kidney: report of 4 cases and review of the literature," Urologia Internationalis, vol. 51, no. 3, pp. 158-163, 1993.

[4] L. Charbit, M.-C. Gendreau, S. Mee, and J. Cukier, "Tumors of the upper urinary tract: 10 years of experience," Journal of Urology, vol. 146, no. 5, pp. 1243-1246, 1991.

[5] Z. Kirkali and E. Tuzel, "Transitional cell carcinoma of the ureter and renal pelvis," Critical Reviews in Oncology/Hematology, vol. 47, no. 2, pp. 155-169, 2003.

[6] M. Valladares Ayerbes, G. Aparicio Gallego, S. Díaz Prado, P. Jiménez Fonseca, R. García Campelo, and L. M. Antón Aparicio, "Origin of renal cell carcinomas," Clinical \& Translational Oncology, vol. 10, no. 11, pp. 697-712, 2008.

[7] A. P. Hart, R. Brown, J. Lechago, and L. Truong, "Collision of transitional cell carcinoma and renal cell carcinoma: an immunohistochemical study and review of the literature," Cancer, vol. 73, pp. 154-159, 1994.

[8] J. W. Lee, M. J. Kim, J. H. Song, J. H. Kim, and J. M. Kim, "Ipsilateral synchronous renal cell carcinoma and transitional cell carcinoma," Journal of Korean medical science, vol. 9, no. 6, pp. 466-470, 1994.

[9] J. E. Bernie, L. Albers, S. Baird, and C. L. Parsons, "Synchronous ipsilateral renal adenocarcinoma, transitional cell carcinoma of the renal pelvis and metastatic renal lymphoma," Journal of Urology, vol. 164, no. 3 I, pp. 773-774, 2000.

[10] I. Gómez García, R. Rodríguez Patrón, S. S. Conde, E. Sanz Mayayo, R. García Navas, and A. Palmeiro, "Renal synchronous tumor: association of renal adenocarcinoma and transitional tumor of renal pelvis, in the same kidney, an exceptional discovery," Actas Urologicas Espanolas, vol. 29, no. 7, pp. 711-714, 2005.

[11] D. M. Murphy, H. Zincke, and W. L. Furlow, "Management of high grade transitional cell cancer of the upper urinary tract," Journal of Urology, vol. 135, no. 1, pp. 25-29, 1981.

[12] G. F. Abercrombie, I. Eardley, S. R. Payne, B. H. Walmsley, and J. Vinnicombe, "Modified nephro-ureterectomy: long-term follow-up with particular reference to subsequent bladder tumours," British Journal of Urology, vol. 61, no. 3, pp. 198-200, 1988. 


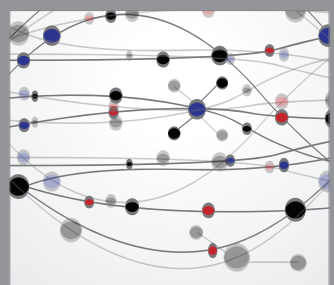

The Scientific World Journal
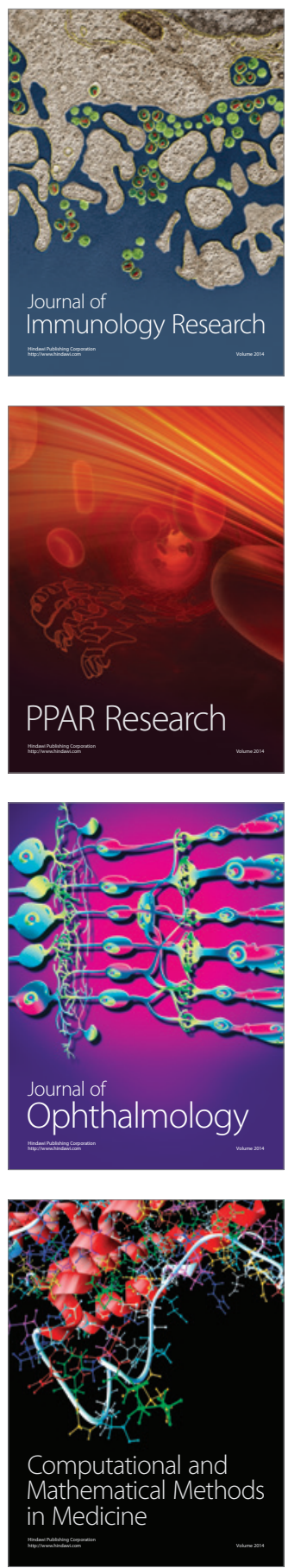

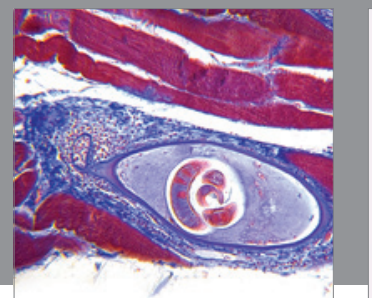

Gastroenterology

Research and Practice
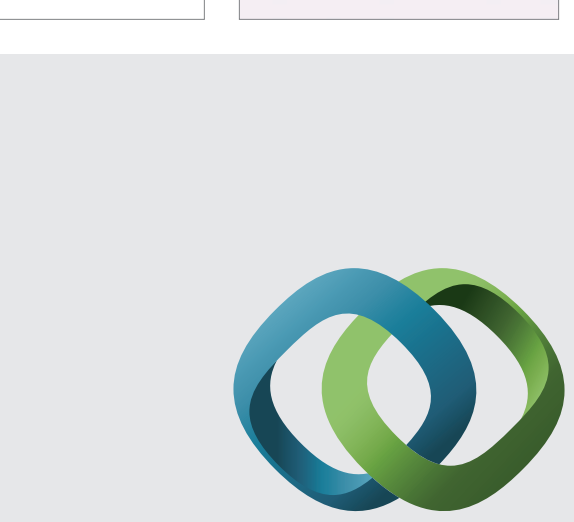

\section{Hindawi}

Submit your manuscripts at

http://www.hindawi.com
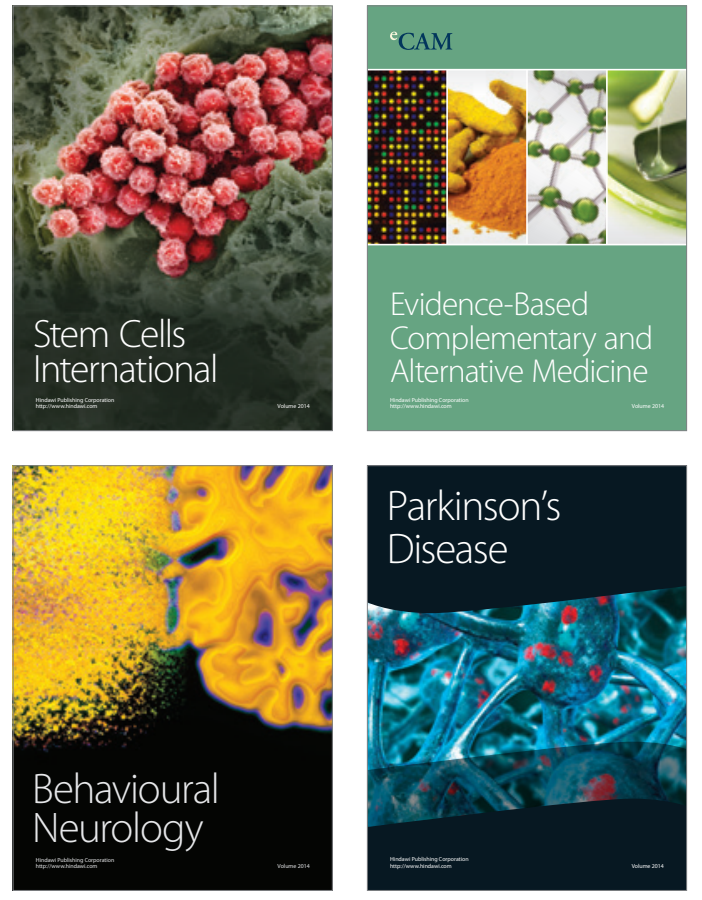
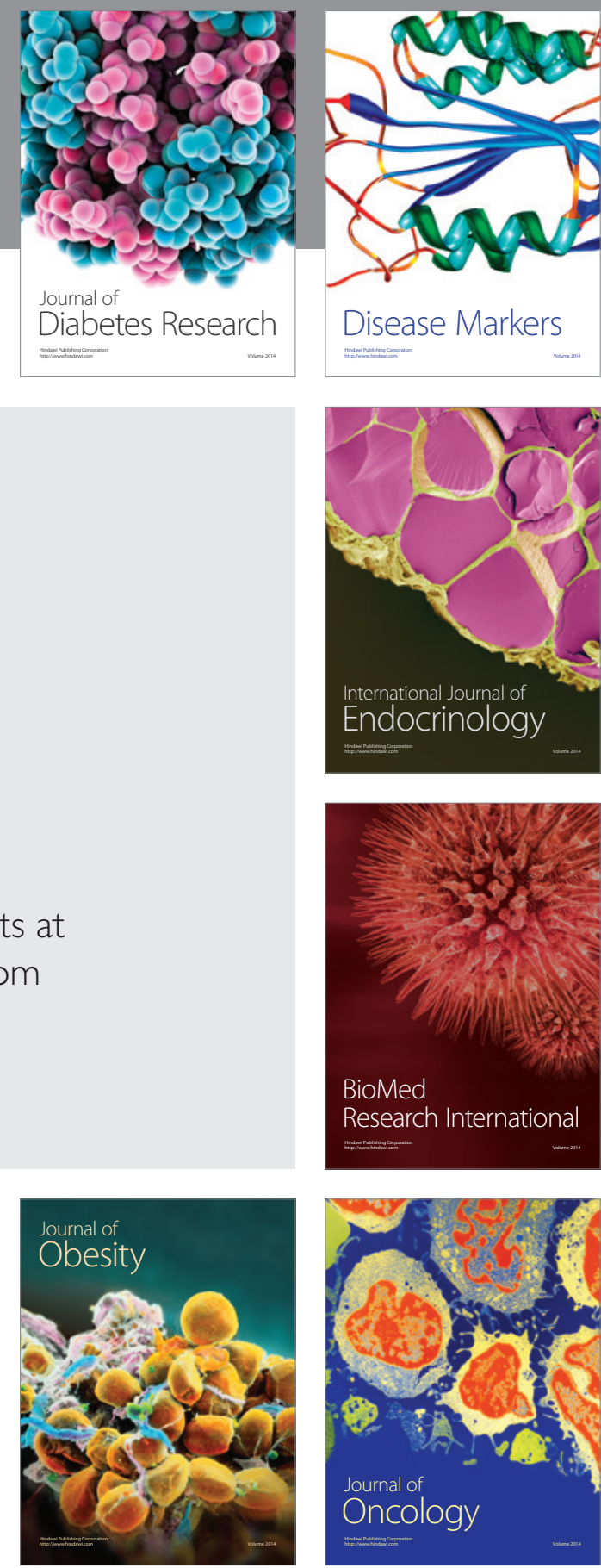

Disease Markers
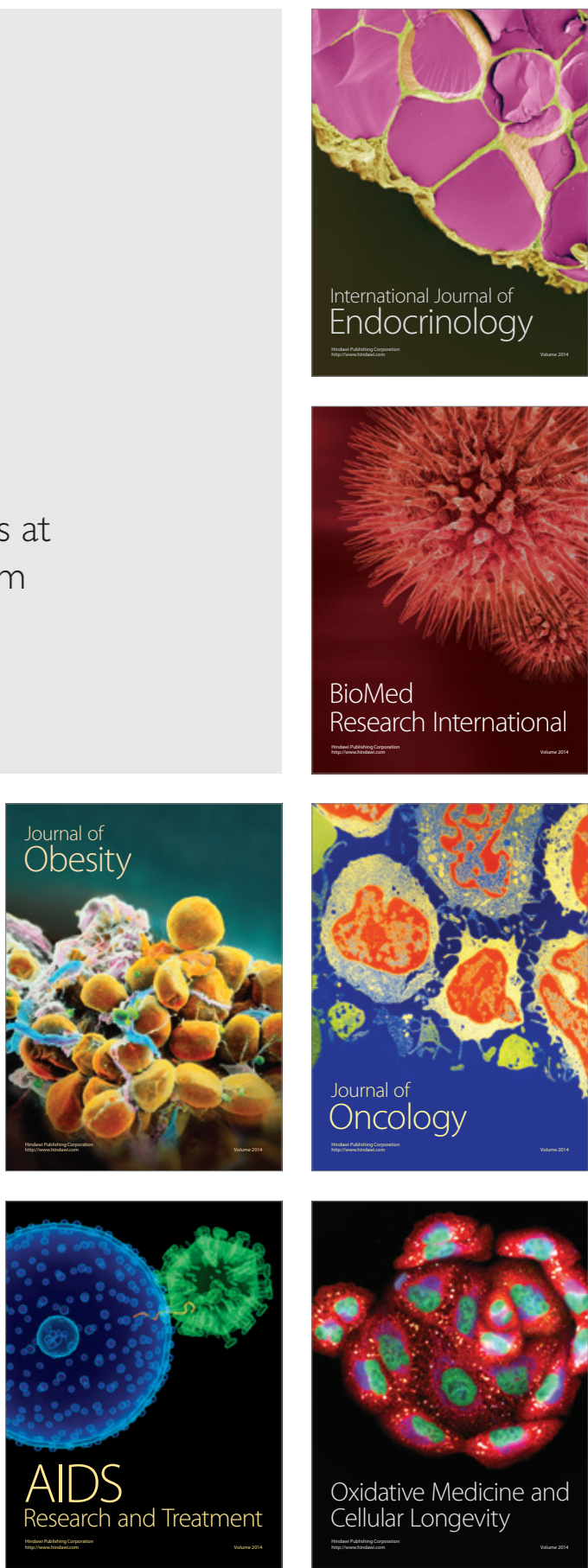